\title{
THE DETERMINANTS OF CUSTOMER PREFERENCES TOWARDS MICROFINANCE SERVICES: A CONSUMER PERSPECTIVE FROM PAKISTAN
}

\author{
Umair Ahmed \\ Institute of Business \& Technology, Karachi, \\ Muhammad Wasim \\ Usman Institute of Technology, Karachi \\ AbdurRehmanAleemi \\ Institute of Business M anagement, Karachi, \\ Fauzan Saeed \\ Usman Institute of Technology, Karachi
}

\begin{abstract}
Purpose:This study helps to understand the successful path of micro-financing, which can plays a vital role in poverty alleviation in Pakistan.

Methodolgy/Sampling:To collect data authors of this paper visited different microfinance institutions (MFIs) like Tameer Micro Financing Bank and Khushali Bank Limited in Karachi. A structured questionnaire was designed for data collection of consumers of microfinance. Statistical data of 100 samples showed $46 \%$ of respondents acquired loan for agricultural purposes while $54 \%$ loans were business based.

Findings:It is observed that male respondents are higher than female. Regression model showed $38 \%$ variation in consumer preference regarding the microfinance services. Statistic in the ANOVA shows the significanceof model. The coefficient of MFI's Approach with negative sign indicates an inverse relationship with that of consumer preferences. It means that MFI agents do not give proper value to the targeted consumers. Finally the amount of loan and interest charged by the MFI's is also having a negative impact on the consumers of micro- finance.

Practical Implications:This study deliver statistical evidence of utilization of funds as well as the consistency of gathered data. Work showed that responded are need to be aquired more knowlwdge about the microfinance services in Pakistan.
\end{abstract}

Keywords: MFIs,Microfinance, Customer Preferences, Pakistan.

Jel Classification: Z13

*The material presented by the author does not necessarily portray the view point of the editors and the management of the Institute of Business \& Technology - IBT

1. Umair Ahmed

:umair03ahmed@gmail.com

2. Muhammad Wasim

: wassym4@gmail.com

3. AbdurRehmanAleemi

: abdurrahmanjan@gmail.com

4. Fauzan Saeed

: fauzansaeedhamid@gmail.com

CIBT-JBS is published by the Institute of Business \& Technology - IBT Main Ibrahim Hydri Road, Korangi Creek, Karachi-75190, Pakistan. 


\section{INTRODUCTION}

Across the world different nations are facing poverty related issue. The emerging crises has created a havoc amongst the citizens of different countries encountering poverty issues, since most of the people in such countries live below poverty line they simply cannot afford necessity and needs of their daily life. This kind of situation can have a negative effect on society and create many difficulties such as shortcoming in health care facilities, high illiteracy rate, decreased quality of life etc. Increased rate of crime, law enforcement problems, security issues, and others in disciplinary actions.

There are several major decision and steps that have been taken by the government and authorities of a country who were facing poverty condition. The main cause is to improve the economy of the country.

Microfinance has been an important tool for the economic growth and poverty alleviation, as it has reached out in many different countries around the world (Wilkes, 2005). MIFs provides microfinance services to their low-income and poor people of the country. In practice, the term is often used more narrowly to refer to loan and other services from providers that identify them-self as MIFs.

In Pakistan there are numerous NGO's, MIF's, MFB's and other welfare trusties who are working for poverty alleviation and they are striving to attain their goals and assignments. State Bank of Pakistan (SBP), Pakistan Microfinance Network (PMN), Pakistan Poverty Alleviation Fund (PPAF) and many more organizations are working for the reduction of the poverty and contributing for economic development of nation as well. In Pakistan there is $33 \%$ to $35 \%$ of the population living below poverty line; it means one third of the population of 180 million is living below poverty line; this miserable situation of the society is very unpleasant (Ameer \& Jamil, 2013). There are number of organizations like Kashf Microfinance Bank, Tameer Microfinance Bank, Khushali Bank, First Women Bank, Akhuwatetc, that are working with the government to overcome poverty problems of the country.

However, as expected, not everything perfect. In Pakistan the consumers of microfinance has some issues with MIFs and also with other factors. In January, 2008 the Global Financial Education Program (GFEC) in partnership with Finrual Bolivia conducted a market research to evaluate customer protection concern and needs. This research is conducted to identify the knowledge and skills that financial service clients must be aware of their rights and responsibilities. Microfinance clients must know about interest rate, collection practice and over indebtedness. Client wants to be treated with respect and dignity MFIs must give full details about the terms and conditions of microfinance services and product of the microfinance. There are several other issues for consumers of microfinance in Pakistan like inflation, security, political interference, etc. This research is conducted to identify the importance of microfinance from the consumer perspective in enhancing their social status which in turn will contribute in poverty alleviation.

\subsection{Problem Statement}

MFIs is playing a vital role in Pakistan for the alleviation of poverty, uplifting the living standards of the poor people, women empowerment, better health facilities etc. But there are some hindrances in the successful path of the micro financing, and that is consumer of micro financing do not understand their rights and responsibilities 
of micro financing institution, they are not totally aware with the product of micro financing that are offer to them.

The basic intended purpose behind study is to find out primarily that what are the factors due to which consumers are coming towards microfinance services and secondarily what are the factors that hold the consumers back who wish to acquire the same. This study is an attempt to address these parameters through an empirical exercise in the context of Pakistan with a particular emphasis on the rural areas where majority of the users of microfinance services can be found.

\subsection{Objectives of the Study}

The main objective of this research is to highlight and find out the key determinants of consumer preferences for microfinance services in Pakistan.

\subsection{Significance of the Study}

This research will help to understand the important factors of the micro financing through which we can decrease the poverty, increase the living standards of the poor people in the country. This study will helps the clients of micro finance to understand their rights and responsibilities. In addition they can get aware the product of micro financing in a more proper manner. This research will also help to reduce some internal and external issues of micro finance institutions of Pakistan as well.

\section{LITERATURE REVIEW}

At present a lot of work has been done by the researchers in this domain. Issues, challenges and success factors in micro financing are now more attractive areas for the researchers.

(Okibo\&Makanga, 2014) [7], conducted a study that micro credit and micro finance services provided by micro finance institutions to their clients to improve their income and reduce their poverty level. Providing small loans to poor people at a very low interest rate this is quite good for the poor people now they can easily start their own business on small set up.

(Durrani, Usman, Malik \&Amad, 2011) [2], conducted a research in which they determined microfinance institutions are playing a vital role in poverty reduction in the country. The maximum respondents were in favor of introducing microfinance service in the country.(Hass, Harmgart\&Meghir, 2012) [1], conduct a study in which they analyze the impact of microcredit in poverty alleviation and education. By the use of microcredit poverty in Bosnia reduced and local businesses flourished as a result they can afford better education for their children.(Jha. S, 2013) [5], conducted a research that in India micro financing has change the life of poor in term of their socio-economic empowerment, and stable livelihoods based on dignity and self-respect. It has a great powerful impact on poverty alleviation and empowerment, especially for the women in India.Chandarsekar\& Prakash, 2010, determine the importance of Information Communication Technology (ITC) this technology is helping the country in reducing poverty specially among the women. By the use of the software women of the countries are getting advantages now women can analyze their opportunity and become empowerment.Idrees, (Ilyas\&Cheema), 2012 [4] conducted the study in which researchers define that micro crediting play a useful role in empowerment of women 
of rural areas of Pakistan. Its impact was very positive, it defined the role between micro crediting and income generating activities. Different NGOs are also providing micro crediting to empower women in rural areas. By the use of these types of programs in different rural areas of the country women are participating in the different fields. Burlington, 1998, stated that micro financing is also useful for young and unemployed individuals, by using this opportunity of micro financing they can set up their own small business. In 1998 self-employed programs were proposed in U.S, France, Germany, Netherlands and many other countries.(Sarumathi\& Mohan, 2011) [9], conducted a research that micro financing is a type of bank service provided to unemployed and low-income individuals who do not have any other means of getting financial service. Microfinance is empowering women creating awareness which finally results sustainable development of a nation. Impact of micro financing is appreciable in bargaining confidence, courage, skill development and empowerment.(Zaidi, Farooqi\&Naseem, 2008) [11], presented a research, they stated that inflation is dangerous for poor people, they can suffer the most and can bear the severest burnt brunt of this economic crises. Due to this inflation, interest rate will increase and therefore the cost of the funds will be increased. Because of this consumer can become bank defaulter and this will increase credit risk as well.

(CGAP's Opinion Survey, 2009) [8], according to this survey due to increase in Financial crises micro financing clients are effecting badly, clients are finding it harder to repay their loans, because of this crisis clients becoming defaulters and chances for fraud will increase.(DannetLiv, 2013) [6], conducted a study, which define that now a days people have too many options and access to borrow loans with different microfinance institutions, repayment of their loans can eventually create risk in losing their assets even their livelihoods, and potential worsening their living condition.(Haq and Khalid, 2011) [3], conducted a research in, which they concluded that security threats are very harmful for the microfinance institutions and for clients as well. Since 2007, over 35,000 civilians have been killed and injured in terrorist attacks, target killing and other accidents.Hytopoulos, 2011, conducted a research in which he presented that through microfinance poverty has reduced in rural areas of Thailand and their income also increased. Its impact was very healthy, their not only improved their standard of life but the literacy rate also increased.Khalid, Shahid, 2014, conducted a study in which he highlight the customer protection in microfinance institution. Microfinance institution must improve their activities in over-indebtedness, transparency, privacy of clients data.

\section{RESEARCH METHODS}

\subsection{Method of Data Collection}

To collect the data, at initial level we visited different branches of micro financing institutions (MFIs) like Tameer Micro Financing Bank and Khushali Bank Limited in Karachi, Pakistan. The respondents were requested for filling the questionnaire. The bank officers of these banks also provide some guidance and help because they are directly engaged with the different micro- finance operations. After gathering all the data we enter it into a specially design software that is Statistical Package for Social Sciences (SPSS) this software was designed by IBM Company. 


\subsection{Sampling Technique}

Two stage sampling procedure has been adopted in this study. In the initial phase two micro finance institutions that is Khushali Bank and Tameer Microfinance Bank were selected on the basis of their broad customer base and relatively stronger relationships and roots with the consumers of microfinance as compared to other MFIs-particularly Khushali Bank has done a lot of significant work in this regards. In the second phase convenient random sampling procedure has been adopted due to time and resources limitations. The basic idea is that each and every individual has to be provided with equal chances of participation, however for the sake of convenience data from the consumers of microfinance from these two institutions have been surveyed only.

\subsection{Sample Size}

A total of 100 consumers from different branched of these two MFIs were surveyed with structured questionnaire in this study.

\subsection{Instrument of Data Collection}

A structured questionnaire was designed for data collection of the consumers of microfinance in this study.

\subsection{Conceptual Framework and Research Model}

Authors of this paper presented a conceptual framework in contents of consumer preferences as given in Figure 1.

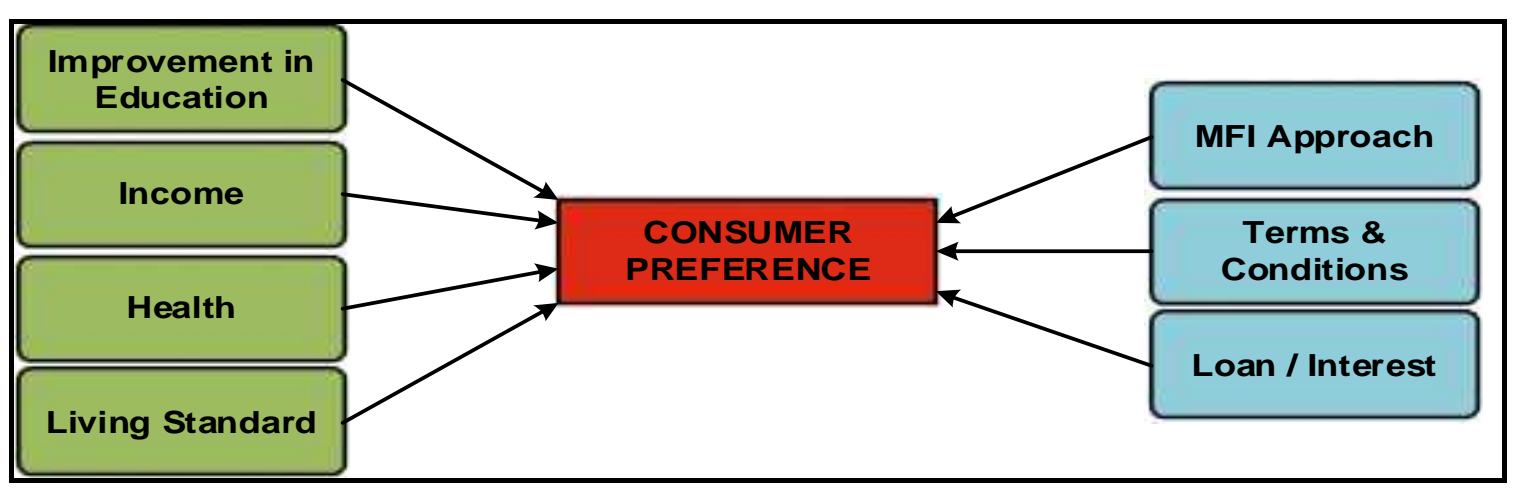

Figure 1. Author's Conceptual Framework

In line standard, with the objectives of this study the above conceptual framework has been developed to understand the consumers' perspective. The main elements are defined as follows:

\subsubsection{Consumers Preference}

Consumer preference is an aggregate indicator developed from the consumers' responses to the questions asked in the questionnaire. The component of consumer preference which is termed as the success factors in this study due to which consumers wish to acquire micro credit, micro loan or microfinance services. These include improvement in economic conditions or the level of income, improvement in health and education needs and improvement in life standards. 


\subsubsection{MFIs' Approach}

Another aggregate indicator considered as an issue in the context of this study which means that how the MFIs or the agents of MFIs approaches and accommodates the customer. It is observed through the responses that many of the respondents complain that the agents at the MFIs were unable to properly explain the procedures associated with obtaining microcredit to consumers.

\subsubsection{Terms \& Condition}

This is another aggregate indicator, indicating the issues in this regards that whether the terms and conditions associated with microfinance services were appropriate or not from the consumers' perspective.

\subsubsection{Loan and Interest Rate}

This aggregate indicator turns out to be the most important from the consumers' side that most of the time it was found that the amount of loan provided to the consumers is believed to be insufficient and also the associated interest rate or the slabs of interest rates provided by the MFIs is considered to be too much high for the high amount of loans. This turns out to be the confounding factor for most of the microfinance consumers as they thought that they might not be able to afford or repay the loan timely.

\subsection{Testing model and Hypotheses}

Given the above conceptual framework the following model and research hypotheses were developed in this study:

$H_{1}$ : there is a significant relationship between consumer preferences and the amount of loan and interest charged by the MFIs

$H_{2}$ : there is a significant relationship between consumer preferences and the MFIs' approach

$H_{3}$ : there is a significant relationship between consumer preferences and the terms and conditions of MFIs.

\subsubsection{Testing Methods}

This study progresses with two types of analytical approaches. In the first stage we tried to explore the descriptive nature of the data i.e. the trend analysis and in the second stage we tried to test the above proposed hypotheses with multiple regression analysis for which the following model has been established;

Consumer preference $=f($ MFIs' approach + Terms and Conditions + Loan and Interest $)$

Or

$c p=\beta_{o}+\beta_{1}$ MFIs' Approach $+\beta_{2}$ Terms \& conditions $+\beta_{3}$ Loan \& Interest $+\varepsilon_{t}-(1)$

Where $c p=$ Consumer Preferences and $\varepsilon_{t}$ is white noise or stochastic disturbance term. 


\section{RESULTS}

This study was conducted with primary data where a sample of 100 consumers of micro finance were surveyed. The sample population in this study is particularly focused towards the consumers in interior Sindh excluding urban areas like Karachi, Hyderabad and Sukkar due to majority of microfinance consumers come from the rural and suburban background. Great care has been carried out to include all the districts of interior Sindh, however with a small sample like this and with so much limited time the following sample distribution has been effectively achieved from each city as presented in the Table 1 .

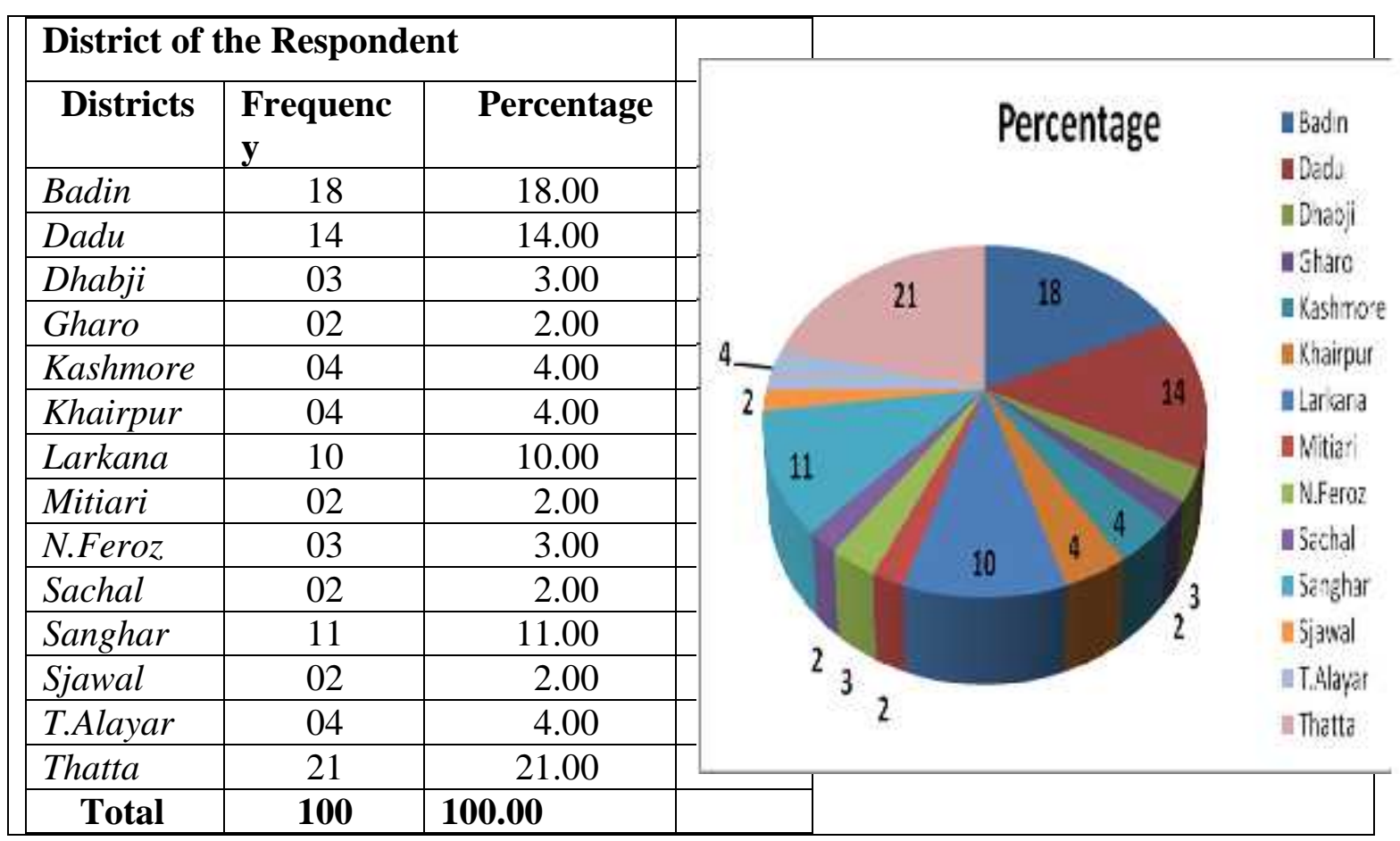

Table 1. District of Respondents: Source (Author's estimation)

Furthermore the Gender distribution of our sample has been provided in the table. That indicates that $67 \%$ of the respondents in our sample are male where as $33 \%$ are female as given in Table 2.

\begin{tabular}{|c|c|c|c|c|}
\hline \multicolumn{3}{|c|}{ Gender Distribution } & \multirow{2}{*}{ Percentage (\%) } & \multirow{3}{*}{$\begin{array}{l}\text { Male } \\
\text { w Female }\end{array}$} \\
\hline Gender & $\begin{array}{l}\text { No. of } \\
\text { Respondents }\end{array}$ & $\begin{array}{l}\text { Percentage } \\
(\%)\end{array}$ & & \\
\hline Male & 67 & 67.0 & \multirow[t]{3}{*}{67} & \\
\hline Female & 33 & 33.0 & & \\
\hline Total & 100 & 100.0 & & \\
\hline
\end{tabular}

Table 2. Gender wise Distribution: Source (Author's estimation) 
Microfinance institutions in Pakistan provides numerous services, however for simplicity and convenience in this study we only deal with two broad categories of services provided namely for Business Purpose and Agricultural Purposes. The category of loan or services acquired by the respondents in our sample are provided in the following table. In our sample of 100 consumers $46 \%$ of respondents acquired loan for agricultural purposes while 54\% loans were business based as shown in Table 3 .

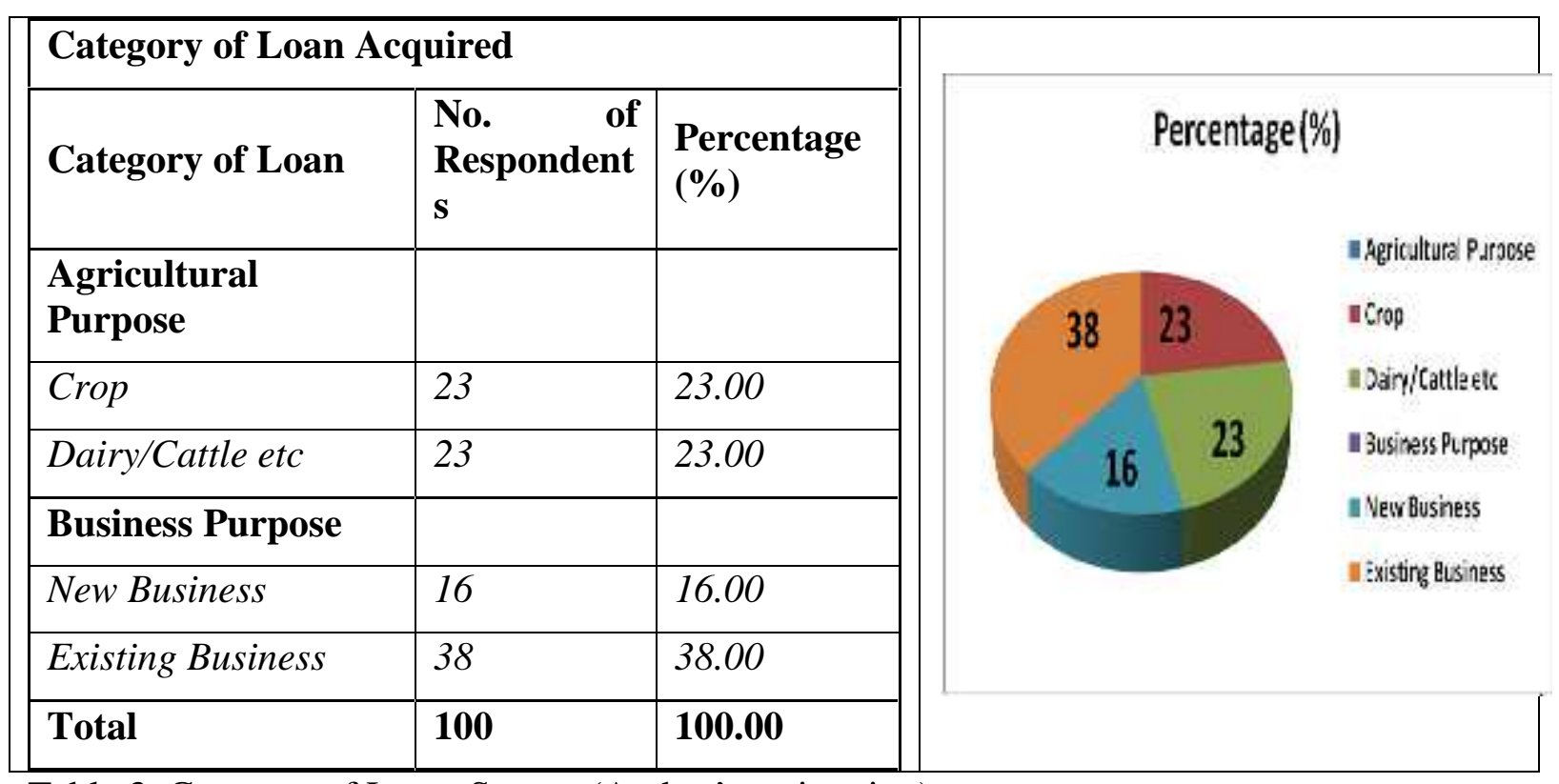

Table 3. Category of Loan: Source (Author's estimation)

Similarly the amount of loan acquired is presented in the table . indicating that the highest amount of loan acquired is 50,001-100,000 with $26 \%$ percent of frequency with 100,001-150,000 following next with $22 \%$ as mentioned in Table4.

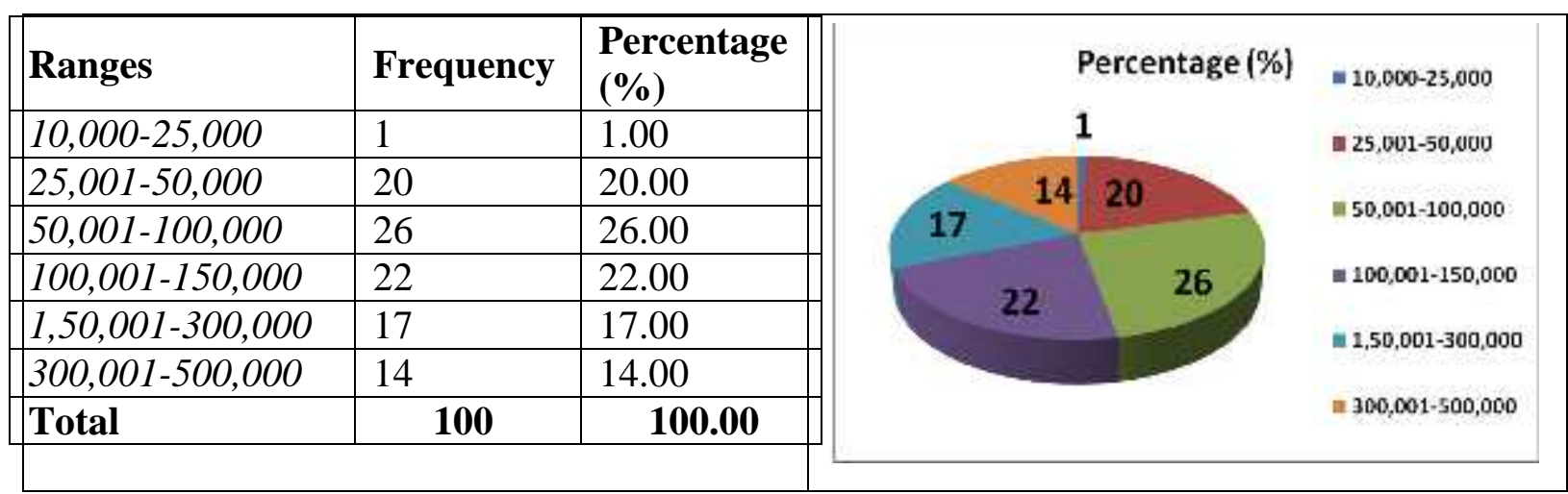

Table 4.Amount of LoanAcquired: Source (Author's estimation)

\subsection{Reliability Statistics}

Reliability means the internal consistency of the data. Since we are dealing with qualitative and primary data, It is of utmost importance to check and the reliability of the data firsthand. In this study the data reliability has been tested with the Cronbach's alpha with the results presented in the following Table 5. 


\section{Reliability Statistics}

\begin{tabular}{|l|l|}
\hline $\begin{array}{l}\text { Cronbach's } \\
\text { Alpha }\end{array}$ & $\begin{array}{l}\text { No. } \\
\text { Items }\end{array}$ \\
\hline 0.787 & 5 \\
\hline
\end{tabular}

Table 5. Reliability Statistics: Source (Author's Estimation)

The reliability statistics presented in the above table with the Cronbach's Alpha indicates quite a promising and strong internal consistency of our data in this study that is $78 \%$ which is well above the threshold or the desirable level of $60 \%$. Hence it is clear that the data utilized in this study represents a high degree of reliability.

\subsection{Regression Results}

\section{Model Summary}

\begin{tabular}{|l|l|l|l|l|}
\hline Model & $\mathbf{R}$ & R Square & Adjusted R Square & Std. Error of the Estimate \\
\hline 1 & $0.615^{\mathrm{a}}$ & 0.378 & 0.359 & 0.54297 \\
\hline
\end{tabular}

Table 6. Model Summary: Source(Author's Estimation)

ANOVA ${ }^{b}$

\begin{tabular}{|l|l|l|l|l|l|l|}
\hline \multicolumn{1}{|l|}{ Model } & Sum of Squares & df & Mean Square & F-Test & Sig. \\
\hline 1 & Regression & 17.231 & 3 & 5.744 & 19.482 & $0.000^{\mathrm{a}}$ \\
\hline & Residual & 28.302 & 96 & 0.295 & - & - \\
\hline Total & 45.533 & 99 & - & - & - \\
\hline
\end{tabular}

Table 7. ANOVA: Source (Author's Estimation) 


\begin{tabular}{|c|c|c|c|c|c|c|}
\hline \multirow{2}{*}{\multicolumn{2}{|c|}{ Model }} & \multicolumn{2}{|c|}{$\begin{array}{l}\text { Unstandardized } \\
\text { Coefficients }\end{array}$} & \multirow{2}{*}{\begin{tabular}{|l}
$\begin{array}{l}\text { Standardized } \\
\text { Coefficients }\end{array}$ \\
Beta $(\beta)$
\end{tabular}} & \multirow{2}{*}{$\mathrm{t}$-Test } & \multirow{2}{*}{ Sig. } \\
\hline & & B & $\mid \begin{array}{ll}\text { Std. } & \text { Error } \\
(S E) & \end{array}$ & & & \\
\hline \multirow[t]{4}{*}{1} & (Constant) & 0.650 & 0.315 & - & 2.063 & 0.042 \\
\hline & $\mathrm{MFI}_{\mathrm{S} \_A p p r o a c h}$ & -0.389 & 0.077 & 0.435 & 5.055 & 0.000 \\
\hline & Terms & -0.290 & 0.084 & 0.296 & 3.439 & 0.001 \\
\hline & Loan/Interest & -0.034 & 0.040 & 0.068 & 5.840 & 0.000 \\
\hline
\end{tabular}

Table 8. Coefficients: Source (Author's Estimation)

The regression results are presented in tables 6 to 8. the $R^{2}$ or the coefficient of determination for our regression model indicate that the proposed model explains for almost $38 \%$ of the variation in consumer preference regarding the microfinance services which is quite a promising value for a small sample like ours. Further the FStatistic in the ANOVA is highly statistically significant and tells that the overall model is significant and well specified. Finally coming towards the slope coefficients of our regression, all the estimated regresses are statistically significant with the expected a priori signs. Furthermore it can be concluded from the estimated regresses that all the estimated regresses or the variables included in our model turns out to be strong determinants of consumers preferences towards microfinance services. Hence all the three proposed hypotheses in this study cannot be rejected in the light of these evidences.

The coefficient of MFI's Approach with a negative sign indicates an inverse relationship with that of consumer preferences. Mean that if MFI's or the agents of MFI's fail to deliver or fail to deal their customers fairly will result in lower customer preference. Similarly any tightness in terms and conditions of microfinance will results in lower consumer preferences and so on. Finally the amount of loan and the interest charged by the MFI's is also having a negative impact on the consumers of micro finance.

\section{CONCLUSION}

This study is related to the determinants of customer preferences towards microfinance services: A consumer perspective from Pakistan. The research shows that microfinance institutions in Pakistan is playing a vital role in poverty alleviation, women empowerment, education, economic condition, improvement in health, improvement in life standards and provides various services. In this study we use primary data, to collect data we visited different branches of MIFs of Tameer Microfinance Bank and khushali Bank Limited in Karachi. This study is related to two extensive category of services provided - Business Purpose and Agricultural Purposes. The statistical data of 100 samples shows $46 \%$ of respondents acquired loan for agricultural purposes, while 54\% loans were business based. In addition the Gender statistical data also showed that male respondents are higher as female respondents. The statistical results showed the consistency of data during this study and it was found to be $78 \%$, which is well above the enviable level of $60 \%$. So it is very 
clear that the data utilized in this study represents a high degree of reliability. Regression model indicate that the proposed model explains for almost $38 \%$ of the variation in consumer preference regarding the microfinance services which is quite a promising value for a small sample like ours. F-Statistic in the ANOVA tells that the overall model is significant and well specified. The coefficient of MFI's Approach with a negative sign indicates an inverse relationship with that of consumer preferences. It means that MFI agents do not give proper value to their target consumers. Finally the amount of loan and the interest charged by the MFI's is also having a negative impact on the consumers of micro finance.

\section{RECOMMENDATION:}

Most of the peoples specially in rural areas and interior backgrounds don't have awareness about the microfinance services so for this Microfinance Institutions (MFI) must give advertisement on different T.V channels, newspapers, billboards. Most of peoples thinks if they take microfinance loan it will create problem for them to repay their loans for that Microfinance Institution (MFI).There should be some system to give proper information about the advantages of microfinance loan in building up their life. Second thing is that microfinance agents must treat their clients fairly give them proper information about microfinance services that which service is suitable for the particular customer. The agents must not only work hard to sell their services but also give value to their clients.

\section{FUTURE RESEARCH:}

This research helps to improve life style of a person as well as poverty alleviation improvement in different fields but there are some problems are there in the successful path of microfinance which effect the process of microfinance. The researcher therefore suggest some topic regarding this which are given below.

1. There is lack of funds for MFIs.

2. MFIs do not use more marketing activities for their promotions and awareness among the peoples.

3. There is a lack of MFIs as compare to commercials bank

\section{REFERENCES:}

Hass, Harmgart and Meghir(November 2012). Microfinance, Poverty and Education. Bosnia

Durrani, K. K., Usman, A., \& Malik, M. I. (November 2011). Role of Micro Finance in Redur Poverty: A Look at Social and Economic Factors. International Journal of Business Social Science, 138-144

Haq, A., \& Khalid, Z. (October 2011). Risks to Microfinance in Pakistan. Survey managen and data consolidation (pp. 1-33). Pakistan: Ayesha Tetlay

Idrees, B., Ilyas, R., \& Cheema, S. N. (March 2012). ROLE OF MICRO CREDIT IN WON EMPOWERMENT IN PAKISTAN. Academic Research International , 464-478

Jha, S. (December2013). Role of Micro-financing in Poverty Alleviation. Apeejay Schoo Management. New Delhi: Financial Practices and Developments

Liv, D. (March 2013). An In-depth Investigation of Saturated Areas. Cambodia Institute Development Study, (pp. 1-83). Cambodia 
Okibo, B. W., \& Makanga, N. (February-2014). Effects of micro finance institutions on pov reduction. Inrernational Journal of current Research and Acedimic Review , 76-95

Reille, X., Kneiding, C., \& Martinez, M. (March 2009). The Impact of the Financial Crisis Microfinance Institutions and Their Clients. CGAP, (pp. 1-4). Washington, DC

Sarumathi, S., \& Mohan, D. K. (September 2011). ROLE OF MICRO FINANCE IN WOME EMPOWERMENT. Journal of Management and Science , 1-10

Wardle, L. (July 2013.). Essential Documents for New Clients: A Toolkit for Finan Institutions. The Smart Campaign

Zaidi, S. A., Farooqi, M. S., \& Naseem, A. (December 2008). The Impact of Inflation Microfinance Clients and its Implications for Microfinance Practitioners. Pakis Pakistan Microfinance Network 